\title{
Aristotelés
}

\section{o Thalétově}

\section{pojetí počátku}

ARISTOTLE ON THALES'S CONCEPTION

OF ORIGIN

\section{RADIM KOČANDRLE}

Fakulta filozofická

Západočeské univerzity v Plzni

Sedláčkova 38

30614 Plzeň

rkocandr@kfi.zcu.cz

\section{ABSTRAKT}

Aristotle's influential conception of the four causes may have tendentiously skewed our view of his predecessors, but even so, we might be able to discern in it the outlines of the original Presocratic conceptions. We could thus see the emphasis on 'origins' as, among other things, the archaic thinkers' focus on the origin and maintenance of life. These are, after all, the reasons which Aristotle himself lists in connection with Thales's conception of origin in the first book of his Metaphysics, where he discusses the connection between moisture, warmth, and life. Interest in these factors is characteristic for archaic philosophy. We can, meanwhile, assume that Aristotle's claim that Thales believed water to be the origin may be due to the Milesian's link to an ancient tradition where water indeed played an important role. Of decisive importance may have been a report, included as part of cosmology - one of the areas Thales was especially interested in that the Earth rests on water." 
Naše povědomí o předsókraticích zůstane silně ovlivněno Aristotelem a jeho koncepcemi, které ve svém výkladu předchůdců uplatnil. Od časů badatelů, jakými byli H. F. Cherniss ${ }^{1}$ nebo J. B. McDiarmid ${ }^{2}$, je známou skutečností, že aristotelské čtení předsókra-

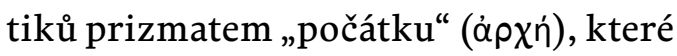
vychází z jeho vlastního pojetí příčin, je výrazně tendenční. Přesto se můžeme ptát, zda Aristotelés nereagoval na určitou významnou stránku přítomnou v jejich myšlení. Podobným charakteristickým rysem mohly být totiž kosmogonické výklady nebo popisy vzniku a typických projevů života. A právě na druhý z uvedených motivů položíme důraz.
Úzce se přitom zaměříme na Aristotelovu referenci o pojetí „počátku“ Thaléta z Mílétu, kterého klade na samotný práh filosofie.

\section{VODA JAKO POČÁTEK}

Když se Aristotelés v I. knize Metafyziky zabývá předmětem a cíli vědění, které nazývá moudrostí, přičemž jde de facto o „první filosofii“, ukazuje, že má v prvé řadě vykládat „počátky a pří-

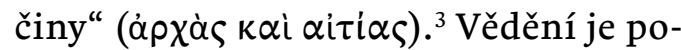
dle něho založeno na poznání počátků a prríčin, nebot každý o něčem ví něco až tehdy, když pozná jeho první příčinu. ${ }^{4}$ Podobně se ostatně vyjadřuje například i na začátku druhé kapitoly I. knihy 
Druhých analytik. ${ }^{5}$ Bezprostředně nato Aristotelés poukazuje k tomu, že existují čtyři druhy příčin: ve smyslu tvaru, látky, účinku a účelu. Ačkoli sám připomíná, že se příčinami zabýval již ve Fyzice, chce se znovu vrátit až ke svým předchůdcům, nebot' i oni podle něho zastávali některé „počátky a př́íčiny“. ${ }^{6}$ Daný krok Aristotelés zdůvodňuje snahou o nalezení případných dalších př́íčin k těm, které sám rozlišuje. Je přitom evidentně veden zájmem celé své pojetí podpořit a zároveň ukázat, že jeho koncepce je vyvrcholením veškerého dosavadního myšlení. Díky tomuto kroku ovšem začlení své vybrané předchůdce do tradice filosofie. ${ }^{7}$

Připomeňme, že klíčový termín „po-

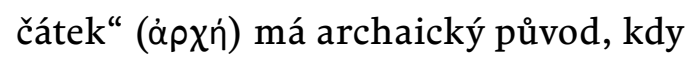
mimo jiné znamenal „zdroj“, „vládu“, „moc“ nebo „suverenitu“.8 Někteří antičtí autoři pak přiznávají prvenství v jeho užití až Anaximandrovi, ${ }^{9}$ ačkoli tím může být míněno jeho použití v novém, specificky filosofickém smyslu. Přesto není jisté, zda jej Mílétané opravdu užívali. Je to však velmi pravděpodobné vzhledem $\mathrm{k}$ jeho výskytu u Homéra. V každém případě v kontextech, v nichž se s termínem à $\rho$ ń u Mílét’anů setkáváme, se jedná výhradně o peripatetické pojetí. Pro Aristotela tento termín nese řadu technických významů. Především jej užívá jako

\footnotetext{
Aristotelés, An. post. l,2,71b19-23.

Aristotelés, Met. 1,3,983b3-4.

Srov. Hobza 2015, s. 53.

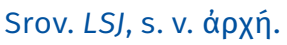

Simplikios, In Arist. Phys. 24,13 = DK 12 A 9; Hippolytos, Ref. 1,6,2 Marcovich = DK 12 A 11.
}

„princip“ (v dalším textu tak budeme termíny „počátek“ a „princip“ používat volně). Mimo jiné může vyjadřovat „příčinu“ ( $\alpha$ ít เov), nebot'Aristotelés doslova soudí, že „každá př́íčina je zároveň počátkem“. ${ }^{10}$ Termín ảpxń tak úzce souvisí s poznáním a s věděním, kdy znamená vlastní princip vědy - příčinu nebo vypovídá o tom, z čeho něco je.

Přihlédneme-li k pasáži v Metafyzice, v níž Aristotelés referuje o svých předchůdcích, můžeme v ní konkrétně číst:

„Většina těch, kdo se první zabývali filosofií, se domnívala, že počátky věcí jsou jen v podobě látky. Nebot’ to, $z$ čeho všechny věci jsou a z čeho nejprve vznikají i do čeho nakonec zanikají - přičemž podstata trvá a mění se jen ve svých stavech -, to nazývají prvkem a počátkem jsoucen. Proto se domnívají, že nic nevzniká ani nehyne, jelikož se vždy uchovává takováto přirozenost."11

„Počátek“ je Aristotelem vymezen jako „podstata“ (oủ $\sigma i \alpha$ ), která je zároveň pokládána za látku. V podobném smyslu se na konci textu objevuje i termín „přirozenost“ ( $\varphi$ uı $\varsigma$ ), který odkazuje $\mathrm{k}$ „prvku a počátku“, přičemž je v něm akcentován imanentní princip pohybu př́ítomný $\mathrm{v}$ podstatě. ${ }^{12}$ Objevuje se přitom klíčová otázka „z čeho“ a rovněž obecná formule, podle níž vše z této podstaty vzniká, aby do ní opět zaniklo.

10

11 Není-li uvedeno jinak, překlady antických autorů pořídil na základě starších překladi̊ V. Hladký a kol.

12 Aristotelés, Phys. II,1,192b20-23. 
Podstata tak měla být nazývána „prvkem“ a „počátkem“, přičemž vše na světě s ní bylo de facto nutně identické a pouze jejím momentálním stavem. Sama se totiž neměla jakkoli měnit, nebot' vždy docházelo pouze k jejím akcidentálním proměnám.

Představený peripatetický rozvrh na dlouhou dobu značně pokřivil naše povědomí o předsókratovské filosofii. Mnozí Aristotelovi předchůdci se na jeho základě od sebe zjednodušeně odlišovali právě tím, který látkový počátek pokládali za podstatu - základní přirozenost. Počátek je přitom převážně identifikován s jedním z prvků - živlů. V učebnicích se pak dané pojetí ocitlo i pod názvem „hylozoismus“. Celá koncepce je ovšem zjevně založena až na pozdních eleatských úvahách o nemožnosti skutečného vzniku a zániku. Pokud Parmenidés ve své době útočil na běžně zastávaný vznik a zánik, lze soudit, že se v daném př́ípadě nejedná o autentické pojetí. G. S. Kirk doslova hovoří o uplatnění Aristotelovy „strnulé metody " na jeho předchůdce. ${ }^{13}$

Přesto se lze domnívat, že otázka po „počátku“ byla jedním ze stěžejních témat předsókratovských myslitelů, byt’ ovšem ve zcela jiné dikci. Jak jsme zmínili v úvodu, Aristotelés mohl reagovat na některé klíčové momenty $\mathrm{v}$ jejich „učení“, které následně přeznačil a začlenil do vlastního výkladu. Jednotlivé prvky mohly být zmiňovány v tak důležitých oblastech, že je Aristotelés následně pokládal za principy svých předchůdců.
Srov. Barnes 1982, S. 41; Graham 2006, s. 65 ; KRS 2004, s. 118.
A jak jsme uvedli, mezi podobné kontexty mohly patřit jak kosmogonické výklady, tak přiblížení vzniku a charakteristických projevů života. V obdobném smyslu bychom ostatně mohli rozumět i následujícím Simplikiovým slovům:

„A ti, kteří předpokládali jeden prvek jako Thalés, Anaximandros a Hérakleitos, z nich každý zaměřil pozornost k působící a rodící povaze onoho prvku. Thalés zaměřil pozornost $\mathrm{k}$ rodící, vyživující, udržující, oživující a formující schopnosti vody. Hérakleitos k životodárnosti a tvořivosti ohně. Anaximenés $k$ vlastnostem vzduchu, který se snadno formuje a snadno přechází na obě strany, jak k ohni, tak k vodě. Jako i Anaximandros předpokládal něco mezi, co se snadno proměňuje." 14

Danou tendenci přitom můžeme sledovat též u Aristotela, nebot' různé aspekty vzniku života a jeho udržení sám vyjmenovává u Thaléta z Mílétu. Projevy života u něho tematizuje zejména v souvislosti s pojetím duše, k němuž jsme ale přihlédli při jiných př́ležitostech a nyní jej ponecháme stranou. ${ }^{15}$ Zaměříme se pouze na téma počátku - principu. Aristotelés přisuzuje Thalétovi princip ve formě vody v I. knize Metafyziky, kde zároveň ukazuje vodu - vlhkost na konkrétních příkladech jako samotný počátek života. V pokračování výše uvedeného textu Metafyziky tak můžeme číst:

Simplikios, In Arist. Phys. 36,8 = TP 2 As 135.

Srov. Kočandrle 2013, s. 8-12; 2014, s. $274-277$. 
„Musí totiž být nějaká přirozenost, at už jedna, nebo vícero, ze které vše jiné vzniká, jí udržováno. Počet a podobu takového počátku neuvádějí ovšem všichni stejně. Thalés, původce takovéto filosofie, říká, že je to voda (proto také hlásal, že Země leží na vodě). Tuto domněnku možná vyvodil z pozorování, že se všechno vyživuje $z$ vlhka a i samo teplo z vlhka vzniká a žije

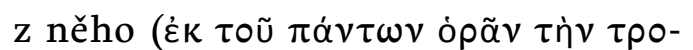

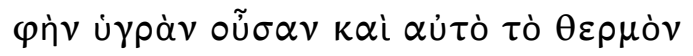

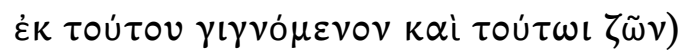
(to, z čeho všechno vzniká, je počátkem všeho). Tuto domněnku přijal také proto, že semena všech věcí mají vlhkou přirozenost a že voda je počátkem

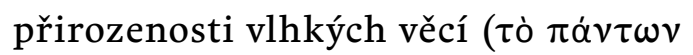

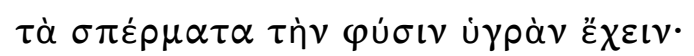

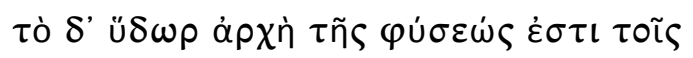

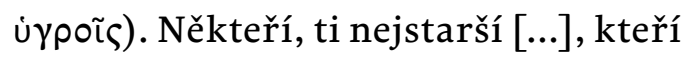
první vyprávěli o bozích, mínili o přirozenosti, že je takto založena. Ókeana a Téthydu učinili otcem vznikání a přísahou bohů vodu, nazvanou u jejich básníků Styx. Nejctěnější je totiž [u nich] to nejstarší, nejctěnější je však přísaha. Nedá se zjistit, zda tento výklad přírody je původní a starobylý, ale o Thalétovi se opravdu říká ( $\lambda \varepsilon \dot{\gamma} \varepsilon \tau \alpha \iota)$, že se v tomto smyslu vyjádřil o první př́ičině (Hippóna by totiž nikdo nezařadil mezi tyto muže vzhledem $\mathrm{k}$ jeho skromnému myšlení). “16

Aristotelés nejprve jasně a jednoznačně vymezuje Thalétův počátek v podobě vody. S vodou spojuje i vlastní umístění Země v univerzu, kterému se

Aristotelés, Met. I,3,983b17 = DK $11 \mathrm{~A} 12$. více věnuje ve spisu $O$ nebi ${ }^{17}$. Následně pak připojuje celou řadu důvodů, které měly Thaléta na základě pozorování podnítit k tomu, aby určil za počátek všeho právě vodu. Jednotlivé důvody však představují pouze Aristotelovy vlastní předpoklady, a nikoli původní Mílétanův výčet. Aristotelés v nich de facto racionalizuje možný směr Thalétových úvah. V každém případě jejich prostřednictvím dobře demonstruje své pochopení mílétské tradice $\mathrm{v}$ těsném sepětí s empirickým charakterem poznání, které sám dále rozvíjí.

Aristotelés následně přechází k principům ostatních myslitelů. Tentokrát je ovšem navýsost stručný a omezuje se pouze na lakonické přiřazení toho kterého principu $\mathrm{k}$ jednotlivým jménům. V rychlém sledu tak uvádí Anaximena a Diogena z Apollónie, kterým přiřazuje za princip vzduch, Hippasos z Metapontu a Hérakleitos z Efesu měli naopak za princip uznávat oheň, zatímco Empedokleovi přiznává již všechny čtyři prvky. Anaxagorás z Klazomen měl pak v Aristotelových očích uznávat neomezené množství principů. Na okraj lze jen poznamenat, že ve výčtu chybí učebnicově očekávaná jména Anaximandra a Xenofana.

Podobně jako Aristotelova zpráva o Thalétově principu vyznívá též Simplikiův komentář k Aristotelově Fyzice, který představuje znění ztraceného Theofrastova spisu Názory př́rodově-

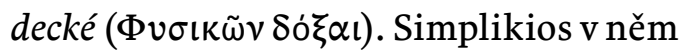
přitom ve velké míře pouze sumarizuje A 14. 
Aristotelovy dohady a zachovává i akcent na empirické pozadí poznání:

„Ty, kteří tvrdí, že počátek je jeden a pohyblivý, označuje [Aristotelés] jako fyziky ve vlastním slova smyslu. Jedni tvrdí, že počátek je vymezený, jako třeba Thalés Examyův z Mílétu a Hippón, který se, jak se zdá, stal ateistou. Tvrdili, že počátek je voda, k čemuž je přivedly jevy, které vnímali. Teplé se totiž živí vlhkým, mrtvé věci vysychají, semena všeho jsou vlhká a veškerá potrava je

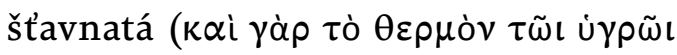

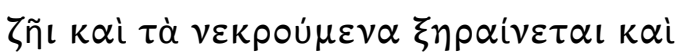

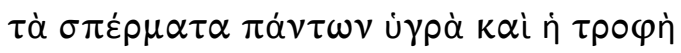
$\left.\pi \tilde{\alpha} \sigma \alpha \chi \cup \lambda \omega \dot{\delta} \eta \varsigma^{\cdot}\right)$. Z čeho pak každá věc je, tím se také přirozeně živí. Voda je počátkem vlhké přirozenosti a drží všechno [všechny věci] pohromadě. Proto usoudili, že počátkem všech věcí je voda, a tvrdili, že Země leží na vodě.“"18

Oproti Aristotelovým volným asociacím a Theofrastovi, který jej v Simplikiově výkladu následuje, můžeme přihlédnout též k Áetiovi, jenž systematizuje údajné Thalétovy důvody do několika bodů, přičemž nově dokládá i kosmologickou úlohu vody. Edice Diels-Kranz ovšem z Áetiova referátu zařadila pouze jedinou větu, týkající se Thalétova spojení s Egyptem. Oba prameny pro Áetia, jak Plútarchos, tak Stobaios, nicméně navíc přinášejí další a téměř identické reference o Thalétově principu v podobě vody.

Jako zdůvodnění dané volby Áetios nejprve užívá obvyklou obecnou formuli, podle níž má z vody vše vznikat a opět do ní zanikat. Podobně jako Aristotelés a Simplikios ovšem doplňuje i další podrobnosti, nebot' Thalés tak měl učinit na základě tří následujících důvodů. Za prvé, semeno všech živočichů je vlh-

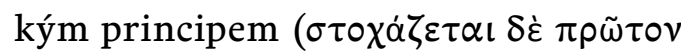

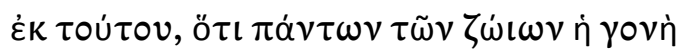

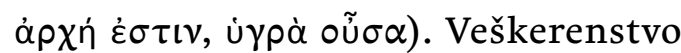
proto může mít svůj původ ve vlhkosti. Za druhé, všechny rostliny jsou vyživovány a nesou ovoce $z$ vlhkosti, ale vadnou, když nejsou zavlažovány ( $\delta \varepsilon u ́ \tau \varepsilon \rho o v$,

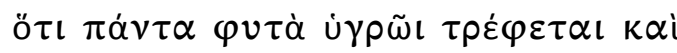

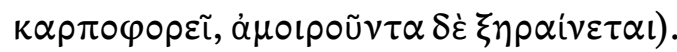
Za třetí, jak samotný oheň Slunce, tak nebeských těles i celého kosmu má být

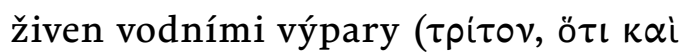

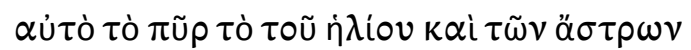
$\tau \alpha \tilde{\varsigma} \varsigma \tilde{\omega} v \dot{\delta} \delta \alpha \dot{\tau} \tau \nu \alpha \dot{\alpha} v \alpha \theta u \mu l \alpha \dot{\sigma} \sigma \sigma l \tau \rho \varepsilon \dot{\varphi} \varepsilon \tau \alpha \mathrm{l}$

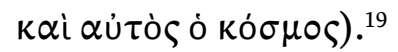

Všechny tři prameny - Aristotelés, Simplikios, Áetios - tedy přinášejí v mírných obměnách podobná znění, obsahující domnělá zdůvodnění Thalétovy volby vody za princip všeho. Ačkoli se jistě jedná pouze o pozdní vývody, můžeme se ptát, nakolik Thaléta adekvátně reflektují a co přimělo Aristotela k tomu, že se cítil oprávněn spojit ho s vodou jako počátkem. Nijak totiž nezastírá, že sám nemá k dispozici přímé prameny a referuje o Thalétovi pouze na základě zprostředkovaných informací.

$\mathrm{V}$ prvé řadě se bezesporu mohlo jednat o zmínky významu vody doložené ve staré tradici, s níž byl Thalés v Aristotelových očích úzce spojen, ze které

Áetios, Plac. 1,3,1 = Dox. $276=$ Graham Ths 16. 
jej ale zároveň vyčleňuje jako „prvního filosofa“. Mohlo se ale také jednat o konkrétní odkazy na Thaléta u Hippóna, jehož jméno se zde objevuje, třebaže jej Aristotelés nehodnotí zrovna v pozitivním světle. Pokud byl ovšem Thalés s Hippónem stran principu běžně spojován, narážka na vlhkost semen či vysychání mrtvých těl by mohla naopak poukazovat k tomu, že reference odkazují právě na lékaře Hippóna. $\mathrm{K}$ Thalétovi mohly být přiřknuty až posléze, nebot Hippón byl obvykle pokládán pouze za kompilátora. ${ }^{20}$

Pokud jednotlivé zformulované důvody nejprve letmo přehlédneme, můžeme konstatovat, že s výjimkou kosmologické role vlhkosti u Áetia jsou dobře srozumitelné i v dnešní době. To, že voda je základní podmínkou pro život, autoři jasně demonstrují na několika př́íkladech různé obecnosti. V zásadě se jedná o běžné zkušenosti, nebot' voda vlhkost je nutnou podmínkou výživy, a tedy i samotného vzniku, vývoje a dalšího udržování života.

\section{VŠE SE VYŽIVUJE Z VLHKA}

Pokud se blíže zastavíme u Aristotelovy pasáže, shledáme, že jako první důvod zmiňuje, že se „všechno vyživuje z vlhka a i samo teplo z vlhka vzniká a žije z něho". Aristotelés ale doslova netvrdí, že z vlhka „všechno vzniká“, nýbrž se z něho pouze „vyživuje“. Naopak uvádí samostatně teplo, které $\mathrm{z}$ něho má vznikat. Případné rozlišení však zde nehraje žádnou roli, nebot' voda je v doplněném textu, obsahujícím obecnou

20 Srov. Guthrie 1962, s. 62; O'Grady 2002, S. 47. peripatetickou formuli, generálně určena za počátek všeho. Mimovolné zdůraznění tepla, které vzniká a žije z vlhka, je jen přirozené, nebot teplo je průvodním znakem a podmínkou života.

V prvé řadě je uváděna výživa všeho z vlhka. Jedná se o jednoznačný a lehce nahlédnutelný fakt, nebot' potřeba pít je pro zachování života neoddiskutovatelná. Může být míněno jak mateřské mléko v prvních fázích vývoje jedince, tak voda či jiná tekutina přijímaná v dalších obdobích života. Podobně potrava, kterou přijímáme, v sobě obsahuje značné množství vody, jak ostatně potvrzuje Simplikios postřehem o štavnatosti veškeré potravy. Celý proces příjmu potravy, jejího zpracování a trávení, se také uskutečňuje za pomoci řady tělesných tekutin, jako jsou sliny nebo žaludeční štávy. Voda přitom přetrvává i ve výměšcích nestrávených zbytků potravy. Podobně rostliny, na které cílí druhý z Áetiových důvodů, musí být zavlažovány, aby neuvadly a nesly plody. Snad můžeme v této souvislosti připomenout i známé lidové rčení: „roste jako z vody“, které $\mathrm{v}$ sobě zachovává mnohé $\mathrm{z}$ těchto motivů.

Pokud se konstituce těla na vodě do značné míry sama zakládá, přičemž jeho další trvání je na jejím stálém příjmu zcela závislé, můžeme dobře porozumět Simplikiovu obecnému tvrzení: „z čeho pak každá věc je, tím se také přirozeně živí“. Lze se oprávněně domnívat, že peripatetická otázka „z čeho“, nesená problémem látkové příčiny a mírííí tak jiným směrem, může právě zde dostávat svůj adekvátní původní význam. 
Thalés musel být bezesporu obeznámen s tím, že celé tělo významně spoluvytvářejí různé tělní tekutiny, které mohl přímo asociovat se životem a s jeho udržením. Podobně jako P. F. O'Grady bychom mohli v prvé řadě zmínit zásadní životní tekutinu - krev. Rovněž lze uvést krev menstruační, o níž Aristotelés tvrdí, že její přirozenost má blízko k prvotní látce. ${ }^{21} \mathrm{Krev}$ přitom vnímá jako skutečnou výživu těla, doslova látku, $\mathrm{z}$ níž je tělo $\mathrm{v}$ prvé řadě složeno. ${ }^{22} \mathrm{Na}-$ skýtá se i výjimečná role plodové vody, v níž je uloženo lidské embryo po dobu svého vývoje v těle matky a jejíž odtok předznamenává brzký porod. Pro tyto a podobné paralely však nemáme žádnou textovou oporu a můžeme proto zůstat jen v rovině spekulací. ${ }^{23}$

Vlhkost rovněž úzce souvisí s nezvratnými změnami, k nimž během života dochází, a přímo s odlišením mládí a stáří. Aristotelés se v Meteorologice zmiňuje o přirozeném zániku ve smyslu „stárnutí a vysychání“ ( $\gamma \tilde{p} p \alpha \varsigma$ к $\alpha \grave{i} \alpha u ̈ \alpha v \sigma(\varsigma) .{ }^{24}$ Stárnutí a vysychání jsou úzce spojené procesy, dobře zakotvené v obecném povědomí. Zatímco mládí je charakteristické vlhkostí, během stárnutí tělo naopak původní vlhkost ztrácí, vysychá. Vlhkost poskytuje tělu plný objem, který se postupně zmenšuje. Konstituce těla tak postupně přichází o svou někdejší pevnost. Až by se chtělo obrazně říci: život nás doslova

\footnotetext{
21 Aristotelés, De gener. animal. I,20,729a30-33.

22 Aristotelés, De part. animal. II,3,650b11-12; II,4,651a14-15.

23 Srov. O'Grady 2002, s. 48-49.

24 Aristotelés, Meteor. IV,1,379a2-4.
}

vyždímá! Mrtvá těla pak rovněž ztrácejí své původní teplo, chladnou a postupně vysychají, jak přímo dokládá Simplikios. Podobně krev je během života teplá, aby po smrti vychladla, až nakonec zcela zaschla. Aristotelés přitom tvrdí, že ve stáří má každý živočich již méně krve, která je navíc hustá a tmavá. ${ }^{25} \mathrm{Na}$ základě podobných příkladů je pak jen přirozené, že život byl v prvé řadě asociován právě s vodou - vlhkem. ${ }^{26}$

Když G. E. R. Lloyd analyzuje protikladné dvojice teplo-chlad a suchovlhko v raně řeckém myšlení, ukazuje, že zatímco „vlhké“ bylo spojené s tím, co je živé, mrtvé bylo naopak často charakterizováno jako „suché“. Homér popisuje

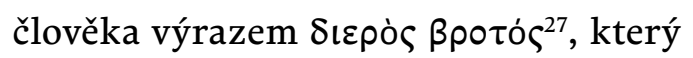

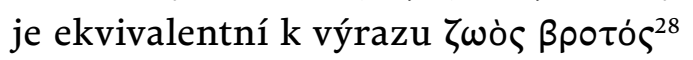
(„žijící smrtelný“), přičemž slovo Sıcpós normálně znamená „vlhký“. Stáří naproti tomu bylo spojováno se suchem. O proměně Odyssea ve starce tak Athéna říká, že vysuší jeho pěknou kưži. ${ }^{29}$ Podobně umírající a mrtvé je suché jako dřevo poraženého topolu. ${ }^{30}$ Mrtví jsou Platónem nazýváni $\alpha \lambda i \beta \alpha \nu \tau \varepsilon \varsigma^{31}$, ve smyslu „bez vlhka“. G. E. R. Lloyd nicméně podotýká, že představená analogie nebyla dokonalá a aplikovatelná ve všech př́ípadech, nebot’ zatímco léto je asociováno s teplem a suchem, zima je naopak charakteristická chladem a vlhkem. ${ }^{32}$

\footnotetext{
25 Aristotelés, Hist. animal. III,19,521a33-34.

26 Srov. O'Grady 2002, s. 47.

27 Homér, Od. VI,201.

28 Homér, Od. XXIII,187.

29 Homér, Od. XIII,398.

30 Homér, Il. IV,487.

31 Platón, Resp. III,387c.

32 Srov. Lloyd 1964, s. 101.
} 
Můžeme ještě přihlédnout i k jiným tradicím, které úzce spojují vodu se životodárnými schopnostmi a mohly Thaléta ovlivnit. Často se u něho spekuluje zejména o egyptském vlivu. Ačkoli není dobré podobným zprávám důvěřovat, reference o spojení Thaléta s Egyptem jsou přece jen poměrně četné. Je možné, že mohou mít své pravdivé jádro již $\mathrm{z}$ důvodu mílétské državy Naukratis v nilské deltě. Život v Egyptě, rozkládajícím se kolem břehů Nilu, se přirozeně s touto velkou řekou výrazně prolínal. Jak dále uvidíme, pravidelné záplavy Nilu byly pokládány za úzce spjaté s vlastním vznikem života. ${ }^{33}$ Egypt’ané byli dokonce podle Aristotela pokládáni za nejstarší z celého lidského pokolení. ${ }^{34}$ Podobně Hérodotos líčí příběh, podle něhož měli být starší pouze Frygové. ${ }^{35}$ Pokud byl Nil přímo spojován se životem, lze v této souvislosti připomenout, že jedno z vysvětlení rozvodňování Nilu přisuzuje tradice též Thalétovi. ${ }^{36}$ Následné vyměřování pozemků z důvodu výběru daní je zase Hérodotem spojeno s počátky geometrie, které mají s Thalétem rovněž úzkou vazbu. ${ }^{37}$ Ačkoli bychom patrně neměli přeceňovat přímou afinitu Nilu k údajné Thalétově volbě vody za počátek, lze ji bezesporu vnímat jako další a významné potvrzení klíčové role vody. ${ }^{38}$

Diodóros, Bibl. hist. I,10,2-3.

Aristotelés, Meteor. 1,14,352b20.

Hérodotos, Hist. II,2.

Áetios, Plac. IV,1,1 Diels-Kranz = DK 11 A 16; $D L$ I,37 Marcovich = DK $11 \mathrm{~A}$ 1; Hérodotos, Hist. II,20 = DK $11 \mathrm{~A} 16$.

Hérodotos, Hist. II,109.

Srov. O'Grady 2002, s. 51-52.

\section{TEPLO VZNIKAJÍci z VLHKA}

Spolu s výživou všeho z vlhka Aristotelés ve své zprávě dále uvádí, že „samo teplo z vlhka vzniká a žije z něho“. Theofrastos u Simplikia přitom Aristotelův vývod opakuje, když zmiňuje výživu tepla z vlhka. Jako v předchozím př́ípadě se Aristotelés opět vyjadřuje v obecné rovině. Pokud měl daný postřeh také vycházet z pozorování, mělo by se jednat o běžně zakoušené jevy spojené s vlhkem. Vedle vlhkosti je teplo bezesporu dalším charakteristickým znakem života. Běžná zkušenost spojuje život právě s teplem a vlhkem. Výše jsme zmínili teplo krve a spolu s vysycháním mrtvých těl i jejich současné vychládání. Aristotelés doslova hovoří o „životním teple“ $(\theta \varepsilon \rho \mu o ́ \tau \eta \varsigma ~ \psi v \chi \iota \kappa n ́){ }^{39}$ jako o jedné z podmínek vzniku živého tvora. ${ }^{40}$

V souvislosti přímého vzniku tepla z vlhka bychom mohli nejspíše akcentovat vznik teplých par stoupajících z příhodného vlhkého prostředí. V prvé řadě lze zmínit vypařování, které mohlo navozovat dojem vzniku tepla, a být tak jeho průvodním znakem. V tomto smyslu můžeme uvést dojem z páry stoupající z připravených horkých pokrmů či nápojů. Ačkoli musely být samy předtím prokazatelně uvařeny nebo ohřáty, právě z nich stoupá horká pára. Podobná je zkušenost v zemědělství s výpary stoupajícími z chlévské mrvy nebo $\mathrm{z}$ různých rozkládajících se či zatlívajících živočišných či rostlinných zbytků. Můžeme jistě akcentovat i teplé výpary a „bublání“ močálů, termálních pramenů či

Aristotelés, De gener. animal. III,2,762a20.

40 Srov. Guthrie 1962, s. 61. 
ranní a večerní opar tvořící se nad vodní plochou nebo krajinou. Sám Aristotelés ${ }^{41}$ tvrdí, že k rozkladu dochází spíše v létě než v zimě, nebot' během zimy vzduch a voda obsahují méně tepla, které nemá dostatečnou sílu, jako je tomu v létě. Takové a podobné zážitky mohly vyvolat dojem vzniku a dalšího vyživování tepla z vlhka. ${ }^{42}$

Pokud Aristotelés ani Theofrastos nezmiňují žádný z podobných konkrétních jevů, zdá se, že jeden z možných př́íkladů dokládá Áetios, když ve třetím z uváděných důvodů pro volbu vody za princip tvrdí, že „jak samotný oheň Slunce, tak nebeských těles i celého kosmu má být živen vodními výpary“. Vypařování, které jsme předtím traktovali pouze na běžných příkladech ze svého okolí, zde získává zcela nový a naprosto charakteristický rozměr přítomný v archaické kosmologii.

Přestože výraz pro „vypařování“

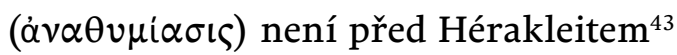
doložen, lze se přirozeně domnívat, že s vypařováním byl Thalés obeznámen, nebot' se jedná o běžně zakoušený jev, který byl určitě mimovolně vykládán dávno před Hérakleitem. Jiné je to ovšem s konkrétním vysvětlením tohoto procesu a s jeho afinitou k oblasti kosmologie. Pokud bychom vzali Áetiovo tvrzení doslova, máme zde před sebou de facto v případě Thaléta první zasazení procesu vypařování do kosmologických měřítek a souvislostí. Celé vyjádření se však spíše nese v obecném tónu, který patrně

\footnotetext{
41 Aristotelés, Meteor. IV,1,379a29-29.

42 Srov. O'Grady 2002, s. 53.

43 Areios Didymos, u Eusebia, Praep. evan. $\mathrm{XV}, 20=D K 22 \mathrm{~B} 12$.
}

vychází z Áetiovy znalosti typických rysů archaických kosmologií. ${ }^{44}$

Vzhledem k nedostatku relevantních informací je Thalétova kosmologie bohužel velkou neznámou. Jistou podporu pro Áetiovu zprávu však nalézáme v jiném jeho textu, který se týká povahy hvězd:

„O podstatě hvězd - planet i stálic: Podle Thaléta je sice zemitá, avšak hvězdy jsou ohnivé.“45

Hippolytos zase u Thaléta spojuje s vodou vlastní pohyb hvězd. ${ }^{46}$ Ačkoli jsou obě zprávy krátké a nejasné, vsazují Thaléta do iónské tradice, v níž jsou vznik a další trvání nebeských těles svázány s vypařováním vlhkosti a s jejím zapálením. Nebeská tělesa jsou obvykle popisována v úzkém vztahu k ohni a k vlhkosti. V případě Anaximandra představují kompaktní kruhy tvořené vzduchem (mlhou), který obklopuje vnitřní oheň. Vznikla však jako přímý pozůstatek po rozlámané kosmogonické planoucí sféře, a nikoli v přímé souvislosti s vypařováním vlhkosti. ${ }^{47}$

44 Srov. Guthrie 1962, s. 67; O'Grady 2002, s. $63-64$.

45 Áetios, Plac. II,13,1 Mansfeld-Runia = DK 11 A 17a.

46 Hippolytos, Ref. I,1,2-3 = TP 1 Th $210=$ Graham Ths 20.

47 Áetios, Plac. II,13,7 Mansfeld-Runia = DK 12 A 18; II,16,4 Mansfeld-Runia = DK 12 A 18; II,20,1 Mansfeld-Runia = DK 12 A 21; II,21,1 Mansfeld-Runia = DK 12 A 21; II,24,3 Mansfeld-Runia = DK 12 A 21; II,25,1 Mansfeld-Runia = DK 12 A 22; II,28,1 Mansfeld-Runia DK 12 A 22; II,29,1 Mansfeld-Runia DK 12 A 22; Achilleus Tatios, Isagoge 19,16 = DK 12 A 21; Hippolytos, Ref. I,6,4-5 Marcovich = 
Anaximenés je vnímal jako plochá ohnivá tělesa vznášející se na vzduchu, která vznikla ze zapálené vláhy vystupující ze země. ${ }^{48}$ Xenofanés je měl zase pokládat za zapálená oblaka, ${ }^{49}$ přičemž Slunce pravidelně vzniká a zaniká. ${ }^{50}$ Hérakleitos popisoval nebeská tělesa jako duté nádoby podobné míse plné ohně. K nám jsou otočena dutinou, v níž hoří oheň pocházející z výparů ze země a moře. ${ }^{51}$

Vlhké výpary tak vytvářejí samotnou konstituci nebeských těles, která se následně navíc z výparů doslova „živí“. Zásadním způsobem s nimi souvisí i pohyb nebeských těles, nebot ta putují po nebi za vlhkostí jako za svou potravou. Svůj hořící oheň totiž musí vyživovat z vlhkosti světa pod nimi. Ačkoli pro nás nemusí být živení ohně z vlhkosti tak bezprostřední, D. W. Graham celý proces vhodně přibližuje příkladem lampy spalující olivový olej. ${ }^{52}$

V obdobném duchu jsou popisovány i obraty Slunce a Měsíce. Aristotelés

DK 12 A 11; Pseudo-Plútarchos, Strom. 2 = DK $12 \mathrm{~A} 10$

48 Áetios, Plac. II,13,9 Mansfeld-Runia = DK 13 A 14; II,20,3 Mansfeld-Runia $=D K 13$ A 15; II,22,1 Mansfeld-Runia = DK 13 A 15; II,25,2 Mansfeld-Runia = DK $13 \mathrm{~A} 16$; Hippolytos, Ref. I,7,4-5 Marcovich = DK 13 A 7.

Áetios, Plac. II,20,3 = DK 21 A 40; II,25,4 = DK 21 A 43; III,2,11 = DK 21 A 44; Pseudo-Plútarchos, Strom. 4 = DK 21 A 32.

50 Áetios, Plac. II,20,3 = DK 21 A 40; II,24,4 = DK 21 A 41; II,24,9 = DK 21 A 41a; Hippolytos, Ref. I,14,3 = DK21 A 33; Pseudo-Plútarchos, Strom. 4 = DK 21 A 32.

51 Áetios, Plac. II,13,8 = DK 22 A 11; II,17,4= DK 22 A 11; II,22,2 = DK 22 A 12; II,24,3= DK 22 A 12; $I 1,27,2=D K 22$ A 12; $11,28,6=$ DK 22 A 12; DL IX,9-10 = DK 22 A 1.

Srov. Graham 2013, s. 49. v referátu o iónské meteorologii doslova tvrdí:

„[Říkají] totiž, že celá oblast v okolí Země byla dříve vlhká [nebo: byla prvotní vlhkostí], byla však vysušena Sluncem. To, co se vypařilo, prý způsobuje vanutí a obraty Slunce i Měsíce, zatímco to, co zůstalo, je moře. Proto se domnívají, že vysoušením se [moře] zmenšuje a nakonec že jednou úplně vyschne." ${ }^{\text {53 }}$

Aristotelovi sekunduje Alexandros z Afrodisiady, který daný náhled připisuje myslitelům různých dob - Anaximandrovi a Diogenovi z Apollónie:

„Někteří z nich totiž říkají, že moře je zbytkem prvotní vlhkosti. Nebot' oblast, která je kolem Země, je vlhká, následně se určitá část této vlhkosti působením Slunce vypařuje a z ní vznikají vanutí a obraty Slunce i Měsíce. Nebot' vysvětlují jejich obraty pomocí těchto par a výparů. A kde je pro ně vlhkosti dostatek, kolem toho je nechávají otáčet. Zbytek vlhkosti v prohloubených místech Země je moře. Proto se také stává působením Slunce pokaždé menším tím, že se vysouší, a nakonec jednou vyschne. Tento názor zastával Anaximandros a Diogenés [z Apollónie], jak tvrdí Theofrastos. “"

Aristotelés ovšem celé pojetí úzkého vztahu mezi vlhkostí světa a nebeskými tělesy, která jsou na vlhkost doslova napojena, podrobuje tvrdé kritice:

53 Aristotelés, Meteor. II,1,353b6 = DK $12 \mathrm{~A} 27$.

54 Alexandros z Afrodisiady, In Arist. Meteor. 67,3-11 = DK 12 A 27. 
„Proto jsou také směšné všechny dřívější názory, že Slunce se živí vlhkostí. Někteří dokonce tvrdí i to, že se kvůli tomu dějí obraty Slunce (slunovraty), nebot tatáž místa nemohou [Slunci] stále poskytovat potravu; to je však na ni odkázané, nebot' jinak zahyne. Vždyt' i oheň, který je zjevný, žije potud, dokud má potravu - a vlhkost je ohni jedinou potravou. Jako kdyby se vzestup vlhkosti dostával až ke Slunci nebo jako kdyby cesta vlhkosti vzhůru byla taková jako při vzniku plamene. Asi proto přijali tento názor i o Slunci.“55

Aristotelés naproti tomu tvrdí, že veškerá voda, která se předtím odpařila, spadne opět v podobě deště. Nemůže tak vyživovat nebeská tělesa, nebot' všechna zpětně kondenzuje ve vodu. ${ }^{56}$

Aristotelés však reaguje z pozice své kosmologické koncepce, která mimo jiné zásadně rozděluje svět na sublunární a supralunární oblast. Zahrnuje přitom nejen různé složení prvků, ale i zcela odlišné dění. Archaické době však nebylo vlastní takové rozpolcení světa na dvě rozdílné oblasti, ale nebeská tělesa byla vnímána $\mathrm{v}$ analogii s meteorologickými jevy v nižších částech atmosféry, stále napojena na vlhkost moře a země. Svět tak byl pojímán jako jedno celistvé kontinuum, rozprostírající se mezi plochou Zemí a nebem. Prostředím, v němž se vše dělo, byl přitom vzduch ve všech svých podobách a proměnách - od temné parné mlhy po jasnou atmosféru. $\mathrm{Mu}$ síme si přitom uvědomit, že mílétské

55 Aristotelés, Meteor. II,2,354b33-355a8. Přel. Z. Kratochvíl.

56 Aristotelés, Meteor. II,2,355a25-32. pojetí vzduchu nejspíše navazuje na epickou tradici, v níž byl termín ảńp $\rho^{57}$ spojen s významy jako „mlha“, „opar“ či „temnota“, jak může být doloženo u Homéra. ${ }^{58}$ Vzduch měl zároveň blízko k prvotní vlhkosti, jejímž pozůstatkem mělo být podle Anaximandra samotné moře. Pro nás je podstatné, že právě vzduch zde obsahuje a vydává i vlhkost, přičemž z něho vzniká vítr, a zajištuje tak celý koloběh vody $\mathrm{v}$ přírodě. Uvidíme, že iniciačním momentem vypařování se mělo stát teplo Slunce. ${ }^{59}$ Zjevný meteorologický charakter iónské kosmologie pak D. W. Graham popisuje doslova jako „meteorologický model“ ${ }^{60}$

Výše jsme uvedli, že třetí Áetiův důvod pro určení vody jako principu, míríící do oblasti kosmologie, můžeme pokládat za pozdní a zastřešující tvrzení založené na typických rysech archaických kosmologií. Lze proto pochybovat, že vychází z konkrétních Áetiových poznatků o Thalétově kosmologii. Přesto bychom jej na Thaléta mohli rámcově uplatnit, nebot' evidentně reprezentuje dobový způsob uvažování o univerzu, který rozvíjeli Thalétovi nástupci.

Na tomto místě můžeme navíc podotknout, že pokud nebeská tělesa představovala mimořádné meteorologické jevy, mohli bychom občasné zmínky o jejich zemitosti ${ }^{61}$ či o existenci dalších

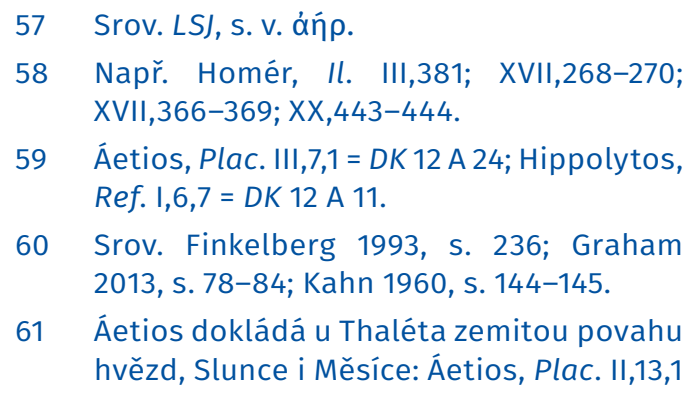

61 Áetios dokládá u Thaléta zemitou povahu hvězd, Slunce i Měsíce: Áetios, Plac. II,13,1 
zemitých těles na obloze vysvětlit v prvé řadě anachronickým přebíráním z nauk pozdní astronomie - zejména z Anaxagory či Diogena z Apollónie. V jiném smyslu by se mohlo jednat o mylný výklad jejich původu $\mathrm{z}$ výparů pocházejících ze země. ${ }^{62}$ U Thaléta se navíc nabízí i možnost, že zmiňovaná zemitá povaha Slunce a Měsíce je založena na jeho údajné předpovědi zatmění Slunce. ${ }^{63}$

Vznik nebeských těles ze zapálených výparů a jejich další udržování prostřednictvím „sání“ vlhkosti z moře a země každopádně dobře ilustruje Aristotelův postřeh, podle něhož „samo teplo z vlhka vzniká a žije z něho“. Oheň nebeských těles zde přitom zastupuje jednu z výrazných forem tepla, jež je důsledkem proměn vody. ${ }^{64}$ Celá představa nejspíše vycházela ze změn skupenství vody, v tomto případě z vypařování. Tyto proměny mohly být akcentovány na základě pouhé všední zkušenosti i bez formulování konkrétní nauky. Pokud vypařování vlhkosti uvozuje celý cyklus koloběhu vody v přírodě, přičemž pro myslitele archaické doby vlhkost dosahovala až k nebeským tělesům, která spoluvytvářela, mohla být voda pokládána za blízký výraz pro celistvost a oživenost světa ve všech jeho proměnách.

Mansfeld-Runia = DK 11 A 17a; II,20,9 Mansfeld-Runia $=D K 11 \mathrm{~A} 17 \mathrm{a} ; \quad I, 24,1$ Mansfeld-Runia = DK $11 \mathrm{~A} 17 \mathrm{a}$.

62 Například v připadě Anaximena: Áetios, Plac. II,11,1 Mansfeld-Runia = DK 13 A 13; II,13,9 Mansfeld-Runia = DK 13 A 14; Hippolytos, Ref. I,7,4-5 Marcovich = DK 13 A 7; Pseudo-Plútarchos, Strom. 3, in: Eusebios, Praep. evan. I,8,3 = DK 13 A 6 .

63 Srov. Graham 2013, s. 49, 51.

64 Srov. O'Grady 2002, s. 52-53.

\section{VZNIK ŽIVOTA}

Viděli jsme, že teplo bylo podobně jako vlhko odedávna vnímáno $\mathrm{v}$ úzkém vztahu k životu. Teplo mimo jiné asociuje životní teplo organismů a představuje jednu z podmínek pro vznik a vývoj života, který bez něho není jako takový myslitelný. Konkrétní popis vzniku života tak může být dalším výrazem vzniku a výživy tepla z vlhka, o nichž se zmiňuje Aristotelés. Přestože $\mathrm{u}$ Thaléta nemáme $\mathrm{k}$ dispozici $\mathrm{v}$ tomto ohledu žádné zprávy, můžeme přihlédnout k Anaximandrovi, jemuž různí autoři přiznávají pozoruhodný výklad vzniku prvních živočichů včetně člověka. Pseudo-Plútarchos ${ }^{65}$ a Plútarchos ${ }^{66}$ se převážně zaměřují toliko na člověka. Áetios, Hippolytos a Censorinus však zmiňují i počáteční podmínky vzniku života:

„Anaximandros [ř́íká], že první živé by-

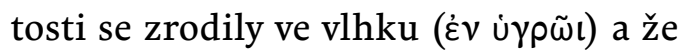
je obklopovala ostnatá kůra. V dalších generacích [s přibývajícím věkem?] vystupovaly na sušší místa, a když se kůra rozlamovala, po krátký čas přežívaly [žily po krátký čas jiným způsobem?]. “67

„Živé bytosti vznikají [z vlhka] vypařovaného působením Slunce ( $\tau \dot{\alpha} \delta \varepsilon \dot{\varepsilon} \zeta \tilde{\omega} \alpha$

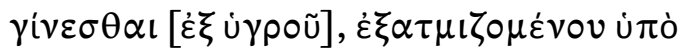

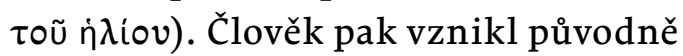
podobný jiné živé bytosti, totiž rybě." ${ }^{68}$

Pseudo-Plútarchos, Strom. 2 = DK 12 A 10. Plútarchos, Quaest. conv. VIII,8,4,730e = DK 12 A 30.

Áetios, Plac. V,19,4 = DK $12 \mathrm{~A} 30$.

Hippolytos, Ref. I,6,6 = DK 12 A 11. 
„Anaximandros z Mílétu si představoval, že $\mathrm{z}$ ohřáté vody a země (ex aqua terraque calefactis) vznikly bud' ryby, nebo živé bytosti velmi podobné rybám. V nich se lidé zformovali a [jejich] zárodky byly zadržovány uvnitř až do puberty. Teprve tehdy praskly a vystoupili z nich muži a ženy, kteří už byli schopni se sami živit." 69

Áetios umíst'uje vznik prvních živých bytostí do vlhka. Hippolytos uvádí základní roli Slunce působícího na vlhko, a způsobujícího tak vypařování vlhkosti. „Vlhko“ však do porušeného Hippolytova textu, který v manuskriptu

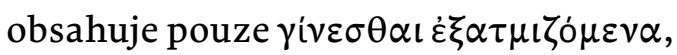
doplnil až H. Diels. Censorinus se pak jako jediný zmiňuje nejen o ohřáté vodě, ale též o zemi. Vzhledem k tomu, že jádrem textů je vznik člověka, je velmi pravděpodobné, že ten je míněn i v případě Áetia. Nejspíše se proto u něho jedná o popis zrodu ryb - rybovitých bytostí, z nichž pochází člověk, a nikoli prvních živočichů vůbec. Přesto se lze domnívat, že jejich zrod byl vzájemně analogický. ${ }^{70}$

Připomeňme, že podle Anaximandra bylo „moře zbytkem prvotní vlhkosti““ ${ }^{71}$ Ta nejspíše v podobě vzduchu - husté mlhy nejprve vyplňovala planoucí sféru, o níž se v prvních fázích kosmogonie zmiňuje Pseudo-Plútarchos. ${ }^{72}$ Po rozlámání planoucí sféry došlo k vypařování

69 Censorinus, De die nat. 4,7 = DK 12 A 30.

70 Srov. Stupñánek 2010.

71 Áetios, Plac. III,16,1 Diels-Kranz = DK 12 A 27; Alexandros z Afrodisiady, In Arist. Meteor. 67,3-11 = DK 12 A 27.

72 této vlhkosti vlivem tepla Slunce, ale i tepla Měsíce a hvězd. Odlišila se tak suchá země od jejího zbytku - moře. Současně vznikla dýchatelná atmosféra. Tím se ustavily podmínky pro vznik suchozemského života. ${ }^{73}$

Vidíme, že se v citovaných textech objevuje vlhko, vypařování, ohřátá voda a země. Vitálními faktory jsou především vlhko a teplo. Klíčovou je aktivita tepla Slunce, zakládající vypařování vlhkosti. K vypařování sice dochází až na základě vnějšího účinku, nicméně pro Anaximandra se mohlo jednat až o druhotné působení na vodu - vlhkost. Právě z ní de facto vzniká teplo, nebot pára se doslova „rodí“ z vody. Vznik tak spočíval v souhře vlhka, země a působení tepla Slunce. Jak dále uvidíme, ohřátou vodu a zemi bychom mohli pochopit jako bahno. Přestože o Thalétovi nemáme žádné bližší informace, lze se domnívat, že sdílel obdobné předpoklady jako Anaximandros. Dokonce se může jednat o původní rámec jeho vlastního myšlení či obecného dobového náhledu. ${ }^{74}$

Vlhko a teplo představují základní podmínky pro vznik života. Thalés se přitom mohl domnívat, že podobně jako teplo vzniká i život spontánně z vlhkosti. Samotný vznik života byl nejspíše úzce spojen s představou samoplození, abiogenezí. Samoplození představuje vlivný a obecně sdílený způsob výkladu vzniku života, který navíc vycházel z přímého pozorování. Obvykle bylo vnímáno ve

73 Áetios, Plac. III,16,1 Diels-Kranz = DK 12 A 27; Alexandros z Afrodisiady, In Arist. Meteor. $67,3-11$ = DK 12 A 27; Aristotelés, Meteor. II,1,353b6 = DK $12 \mathrm{~A} 27$.

74 
spojení s některou rozkládající se látkou za působení vlhka a tepla. ${ }^{75}$

Samoplození přitom nepředstavuje pouhý archaický koncept, nýbrž velmi dlouho udržované vysvětlení vzniku různých životních forem. Významným zastáncem samoplození byl Aristotelés, podle něhož tímto způsobem vznikají nejen rostliny, ale též různé druhy živočichů jako hmyz, některé ryby a ptáci. ${ }^{76}$ Koncepci samoplození je možné nalézt u celé řady dalších antických autorů, jako jsou Epikúros ${ }^{77}$, u něhož lidé vzešli ze zahřátého bahna, nebo Lucretius $^{78}$, který se domníval, že život vznikl z rozměklé země. $V$ ní díky nadbytku tepla a vlhkosti rostly dělohy obsahující embrya prvních živočichů. Proto se také zemi oprávněně říká matka. Někteří živočichové se podle něho navíc rodí z vlhka a tepla i dnes. Diodóros, který žil v 1. století př. Kr., $\mathrm{v}$ tomto smyslu přibližuje proces kvašení, ${ }^{79}$ přičemž přináší zprávu, podle níž tak Egyptané vysvětlovali vznik myší. ${ }^{80}$ Poukazuje přitom na životodárnost bahna Nilu, které zůstávalo po pravidelných záplavách. ${ }^{81} \mathrm{U}$ Diodóra můžeme nalézt i možnou analogii s Anaximandrem, když tvrdí, že díky působení tepla Slunce vznikl život ve vlhké zemi, kde se kvašením objevily

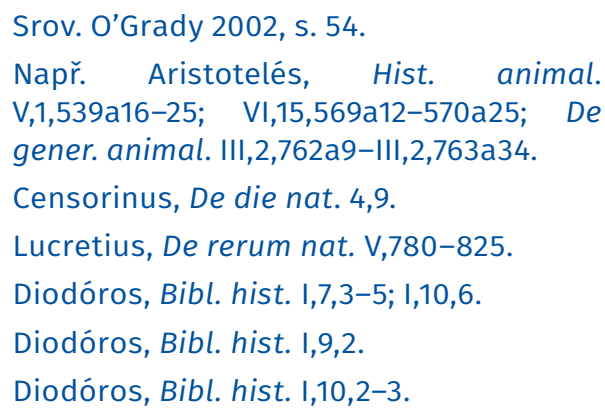

blány s embryi. Převahou toho kterého živlu se pak rodí ptáci, ryby nebo suchozemské bytosti. ${ }^{82}$ Ovidius zase doslova uvádí, že země samovolně vydává různé formy života, které pocházejí ze spojení vlhka s teplem. ${ }^{83}$ Samoplození hraje důležitou roli i v křestanské tradici, nebot' zatímco Bůh stvořil vyšší formy života, v knize Genesis můžeme číst, že hmyz pochází z vod. ${ }^{84}$ Podobně se v 16. století francouzský lékař Jean Fernel domníval, že nižší formy života vznikají v bahně řek, zatímco hmyz pochází ze zvířecích mršin. Ačkoli v případě živočichů se výklad samoplození přestal užívat během 18. století, u jednobuněčných organismů byl zastáván až do poloviny 19. století, kdy byl konečně opuštěn díky práci Louise Pasteura. ${ }^{85}$

Jak jsme viděli, vedle vlhkosti a tepla byla za další významný činitel vzniku života pokládána země. Je přitom zajímavé, že pokud jsou principy Aristotelových předchůdců úzce spojené se vznikem života, jak se domníváme, sám Aristotelés v Metafyzice explicitně uvádí, že zemi nikdo za princip nepokládal $\mathrm{z}$ důvodu její hrubé struktury. ${ }^{86}$ Podobně se vyjadřuje též ve spisu $O d u s ̌ i^{87}$. Vhodným kandidátem pro podobnou peripatetickou systematizaci by přitom mohl

\footnotetext{
82

83 84

s
Srov. Campbell 2000, s. 153; 2006, s. 27;
Guthrie 1986, s. 39-42, 116; Kahn 1960, s. 111-112; Loenen 1954 , s. 221 ; O'Grady 2002, s. 56-57.

Diodóros, Bibl. hist. I,7 = DK 68 B 5,1.

Ovidius, Metam. I,416-437.

Genesis 1,20. Srov. Campbell 2000, s. 153; 2006, s. 27;
Guthrie 1986, s. 39-42, 116; Kahn 1960, Aristotelés, Met. I,8,989a5 = DK $21 \mathrm{~A} 36$. Aristotelés, De an. 1,2,405b8.
} 
být Xenofanés, jemuž zemi jako princip někteří autoři přece jen připisují. Právě u něho totiž opakovaně nalézáme různé zmínky o klíčové roli země:

„Nebot'všechno je ze země a k zemi také cílí." 88

Spolu se zemí se zároveň u Xenofana často objevuje i voda:

„Země a voda je všechno, co se rodí a roste. “ 89

Země a voda jsou podobně doložené též v jedné z možných Xenofanových reakcí na Homéra (Il. VII,99):

„Vždyt' jsme všichni zrozeni ze země a také $\mathrm{z}$ vody. “90

Země přitom hraje výchozí roli i ve známé Xenofanově cyklické teorii, podle níž se země mísí s mořem a mění se v bahno, které zachovává otisky předchozího života. ${ }^{91}$ Vlhko, teplo a jistá podoba země hrají zásadní roli i v popisu života u Anaxagory:

„Živé bytosti povstaly z vlhka, tepla a ně-

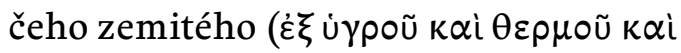
$\gamma \varepsilon \omega \dot{\delta}$ ous), poté vznikají ze sebe navzájem - a to tak, že samci z pravých částí, samice pak z levých." 92

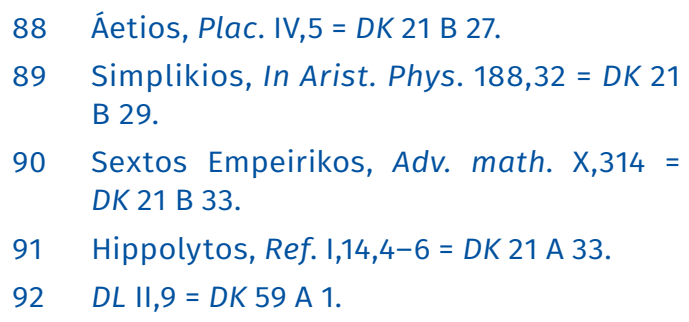

Když Empedoklés popisuje vznik živých bytostí v rámci kosmického cyklu, ukazuje, že jejich části nejprve vyrůstaly ze země: 93

„Mnoho ze země vyrostlo hlav, jež bez krku byly, nahé bloudily paže, jež byly zbaveny plecí, oči samotné bloudily, kterým zas chyběla čela." ${ }^{94}$

Tyto části se postupně spojují do vyšších celků, až se následně vytvoří

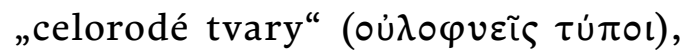
stále však rostoucí ze země. ${ }^{95} \mathrm{~S}$ obratem kosmického cyklu ale přijde doba vlády Sváru, dojde k rozdělení těchto bytostí, a tedy $\mathrm{k}$ diferenciaci pohlaví. Dnešní živočichové tak již nerostou ze země, ale doslova „ze sebe navzájem“ ( $\left.\delta \iota^{\prime} \dot{\alpha} \lambda \lambda \dot{n} \lambda \omega v\right) .{ }^{96}$

Archeláos, který působil kolem roku 450 př. Kr. v Athénách, měl popisovat zrod živých bytostí podobně přímo ze země:

„Ř́íá, že živé bytosti se rodí ze země, která je teplá a vydává jako potravu bahno (ìùv), podobné mléku. Takto země vytvořila i lidi. “97

Bahno nepochybně zastupuje i vodu, již obsahuje, přičemž představuje mateřskou výživu, kterou země poskytuje

Simplikios, In Arist. Phys. 300,21-24= DK 31 B 96.

94 Simplikios, In Arist. De caelo 586,12; 587,1-2 = DK 31 B 57.

95

Simplikios, In Arist. Phys. 381,31-382,3 = DK 31 B 62.

96 Áetios, Plac. V,19,5 = DK 31 A 72.

$97 \quad D L I, 17=D K 60 \mathrm{~A} 1$. 
svému potomstvu. Stejný motiv se objevuje rovněž u Platóna. ${ }^{98}$ Theofrastos v souvislosti se záplavami v Egyptě soudil, že vegetaci plodí směs země a vody. ${ }^{99}$ Spojitost vzniku života s vodou či s vlhkostí země může být přitom nejen založena na prosté zkušenosti, ale zároveň jde o zhodnocení prastaré tradice. V ní je bohyně Země (Gaia) pokládána za skutečnou rodičku, sama je však oplodněná vlhkostí svého manžela, boha nebes. Zatímco Aischylos hovoří jednoduše o nebi, z něhož padá oplodňující déšt', Eurípidés již mluví o Aithéru. ${ }^{100}$ Aristotelés se na Eurípida přímo odvolává, když pojednává o zemi milující déšt majestátního nebe. ${ }^{101} Z$ Země tak hraje roli média, $v$ němž se projevuje vlhkost a z něhož může za působení tepla vznikat život. Konkrétním výrazem života je pak duše, která byla často pokládána právě za druh teplého výparu. ${ }^{102}$

\section{SEMENA A PŘIROZENOST VLHKÝCH VĚCí}

Jako další z důvodů pro údajný Thalétův výběr vody za princip Aristotelés zmiňuje, že „semena všech věcí mají vlhkou přirozenost". Obdobně soudí i Simplikios, když tvrdí: „semena všeho jsou vlhká“. Pro Áetia se dokonce jedná o vůbec první z bodů, které uvádí: „semeno všech živočichů je vlhkým principem“. Ve svém komentáři Aristotelova spisu

Platón, Menex. 237e-238a.

Theofrastos, Hist. plant. 3,1,5-6.

Aischylos, zl. 44; Eurípidés, zl. 839.

Aristotelés, Eth. Nic. 1155b1-3.

Srov. Guthrie 1962, s. 386; 1965, s. 343; 1986 , s. 30-31; O'Grady 2002, s. 50-52.
O nebi navíc Simplikios přináší mírně upravené znění:

„Poté, co [Aristotelés] ukázal, že počátky těles nemohou být bezmezné a že je nutné, aby byly vymezené, pokud jsou jednoduché pohyby vymezené, přechází k těm, kteří tvrdí, že je jeden prvek. Jelikož je jich víc, každý předpokládal jiný jeden prvek. Thalés z Mílétu a Hippón vodu, protože viděli, že z vody vznikají semena živých bytostí a výživa živočichů

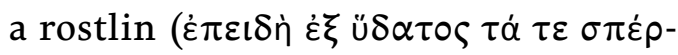

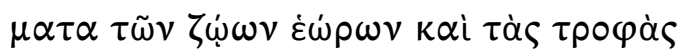

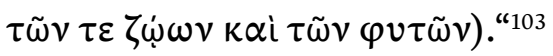

Zatímco Aristotelés a Simplikios užívají shodně termín $\sigma \pi \varepsilon \dot{\rho} \mu \alpha$, Áetios naproti tomu termín yovń. Jedná se přitom doslova o semena všeho, tedy jak živočichů, o nichž hovoří Áetios a v druhém z textů i Simplikios, tak rostlin. Ačkoli jsou semena rostlin obvykle tuhá a zdánlivě suchá, obsahují vlhkost, kterou také potřebují k vyklíčení. O výživě rostlin z vlhka ostatně hovoří Áetios ve druhém bodě svého zdůvodnění. Je to právě schopnost klíčit působením vlhka a tepla, co je pro semena příznačné.

Aristotelés ale může mít především na mysli semena živočichů. Pokud jsme výše uvedli, že jedním z jeho možných textových pramenů byl Hippón, naskýtá se zde další z důkazů. Hippón měl totiž podle Aristotela pokládat duši za vodu, přičemž tak argumentoval na základě vlhkosti semene, které je prvotní duší: 104

103 Simplikios, In Arist. De caelo 615,8 = TP 1 Th 431.

104 Srov. O'Grady 2002, s. 59. 
„Někteří z nich, kteří měli ještě hrubší představy, prohlásili duši za vodu, jako Hippón. Důvodem jejich domněnky patrně je, že původ [sperma?] všeho

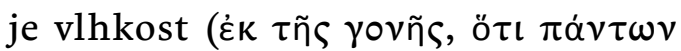

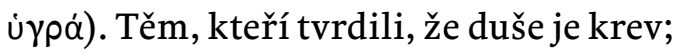

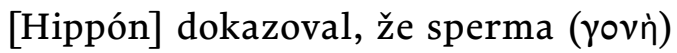
není krev. Toto je však [podle něho] původní duší."105

Podobně se o něm vyjadřuje i Hippolytos:

„Hippón z Rhégia však pravil, že počátky jsou vlhko, tedy voda, a horko, tedy oheň. $Z$ vody prý vznikl oheň, přemohl moc té, z níž se zrodil, a tak ustavil svět. Duši říká někdy mozek, jindy voda; nebot i sperma je nám zjevné za vlhka ( $\gamma \alpha \dot{\alpha} \rho$

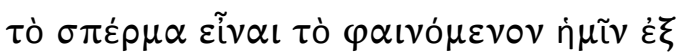

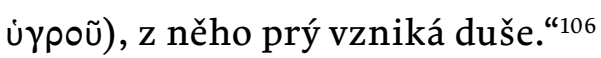

Semena živočichů jsou naprosto zřejmým počátkem života. Mají vlhkou povahu a vzniká z nich život, který si tak jednotlivé generace předávají. $Z$ vlhka tím vznikají bytosti, jejichž vlastní přirozenost je rovněž vlhká. I proto ve výčtu jednotlivých důvodů Aristotelés u Thaléta dále dodává, že „voda je počátkem přirozenosti vlhkých věcí“. Výše jsme viděli, že Aristotelés v dané pasáži užívá

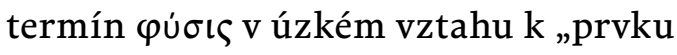
a počátku“, tedy k vlastní podstatě, kdy je akcentována její imanentní schopnost

Aristotelés, De an. 1,2,405b2 = DK 38 A 10. Přel. Z. Kratochvíl.

Hippolytos, Ref. I,16 = DK 38 A 3. Přel.

Z. Kratochvíl. K otázce vztahu duše, resp. mysli a mozku $v$ současném kontextu viz Polák 2013. pohybu a změny. D. W. Graham překládá

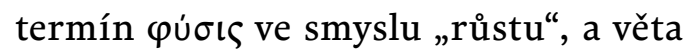
tak získává doslovný smysl, podle něhož je voda počátkem růstu vlhkých věcí. ${ }^{107}$ V souvislosti s vlhkou povahou věcí pak P. F. O'Grady upozorňuje na odpradávna známou tavitelnost kovů. Mohlo se jednat o další z momentů podporujících představu o vlhké podstatě mnoha věcí, která však nemusela být na první pohled vždy patrná. Sám Aristotelés potvrzuje vlhkou povahu mnoha kovů, když v Meteorologice ${ }^{108}$ tvrdí, že mohou být taveny žárem, přičemž přednost vody před kovem zmiňuje $\mathrm{v}$ dané souvislosti i v Metafyzice ${ }^{109} \cdot{ }^{110}$

\section{ARISTOTELOVA}

\section{RACIONALIZACE}

Ohlédneme-li se za jednotlivými důvody pro volbu vody za počátek, které nám Aristotelés předkládá, můžeme se ptát, proč mezi nimi v prvé řadě nefiguruje schopnost vody procházet různými skupenstvími. Že se voda z kapalného skupenství působením tepla mění v páru a v chladu se změní v pevný led, je přitom běžná zkušenost, která musela být Thalétovi dobře známa. Jde navíc o poznatek, který by dokonale zapadl do Aristotelovy představy podstaty a jejích proměn. Rovněž nejsou ani rámcově zmíněny naplaveniny bahna, jež s sebou přináší voda a jež se po jejím odpaření mění v tvrdou zemi, asociující kameny. Jimi by se mohlo uzavřít

Srov. Graham 2010, s. 28.

Aristotelés, Meteor. IV,10,389a8-9. Aristotelés, Met. V,4,1015a9-10. Srov. O'Grady 2002, s. 59-61. 
celé schéma proměn, které doxografie přináší až pro Anaximena, u něhož jsou jednotlivé složky světa - od ohně po kameny - vyloženy prostřednictvím zředování a zhuštování vzduchu. ${ }^{111}$ Až u třetího z Mílétanů tak máme doložen konkrétní proces změny. Jak ale upozorňuje D. W. Graham, musíme si uvědomit, že dnes vycházíme z naší vlastní fyzikální koncepce světa, kdy například led pokládáme za jedno ze skupenství vody. Nemůžeme však mít jistotu v tom, jak Thalés ve své době ty to proměny vody opravdu vykládal. ${ }^{112}$

Aristotelés nepřináší a zjevně se ani nepokouší přinést vyčerpávající výčet, nebot' předkládá pouze některé charakteristické momenty. Po všech uvedených důvodech navíc náhle činí v textu krok stranou a vrací se ke staré tradici, z níž předtím Thaléta vyčlenil. Pokud uváděl vlhkou přirozenost semen a přirozenost vlhkých věcí, měli se obdobně o přirozenosti vyjadřovat ti, „kteří první vyprávěli o bozích“. Evidentně si je vědom výrazné analogie hlavních znaků mezi Thalétem a starou tradicí, v níž byli Ókeanos, Téthys a Sty ${ }^{113}$ obdobně pokládáni za původce vzniku:

„K hranicím Země ted' jít mám úmysl, dárkyně plodů, / matka, kde bydlí Téthys a Ókean, prapůvod bohů [...]."

Hippolytos, Ref. I,7,3 Marcovich = DK 13 A 7; Simplikios, In Arist. Phys. 24,26= DK 13 A 5.

Srov. Graham 2006, s. 51-52; Guthrie 1962, S. 61; O'Grady 2002, s. 59, 61-63.

113 Homér, Il. XV,37.

114 Homér, Il. XIV,200-201. Přel. O. Vaňorný.

Ókeanos, věčná řeka obtékající Zemi, z níž pramení veškeré řeky a moře, ${ }^{115}$ je považován doslova za „prapůvod všech“116, a stává se tak pravým rodičem.

Přestože je podle Aristotela Thalés s touto starou tradicí částečně spojen, zároveň ho od ní zř̌etelně odlišuje a přivádí do tenat filosofie. Nezahrnuje ho tak mezi teology či „smíšené teology“, mezi něž počítá Ferekýda ze Syru, nebot’ se neměl vyjadřovat pouze myticky. ${ }^{117}$ Ferekýda přitom Diogenés Laertios pokládá za prekurzora italské větve filosofie, přičemž stejnou roli v rámci iónské větve svěřuje právě Thalétovi. ${ }^{118}$ Pro nás je zajímavé, že Ferekýdés, který vytvářel různé etymologie, zároveň údajně vyložil pramen Styx jako „proud spermatu“119. Zmíněná Thalétova afinita ke staré tradici je nicméně „dotekem“ náboženských souvislostí, které bychom u něho měli jinak očekávat. ${ }^{120}$

Pokud se porozhlédneme dále po všech Aristotelových racionalizujících důvodech, které měly Thaléta vybídnout k tomu, aby pokládal vodu za princip, vidíme, že se zakládají na zkušenosti a pocházejí z různých oblastí - z fyziologie, biologie, meteorologie nebo z kosmologie. Na žádný z nich přitom Aristotelés neklade důraz na úkor ostatních. Jednotným jmenovatelem je mu vznik a udržení života z vlhka. Vzhledem

115

116 117 118 119 120
Homér, Il. XXI,195-197.

Homér, Il. XIV,246.

Aristotelés, Met. XIV,4,1091b8 = DK 7 A 7 . DL I,13 Marcovich.

Pseudo-Galénos (Porfyrios), Ad Gaur. 34,26 Kalbfl. = DK 7 B 7. Přel. Z. Kratochvíl.

Srov. O'Grady 2002, s. 75; Kratochvíl 2010, S. 205. 
k tomu, že důvody jsou uvedeny takříkajíc najednou, vyjevuje se tím mimoděk i charakter raného myšlení, v němž se jednotlivé sféry přirozeně prolínaly. Thalés je tak stále pevně usazen v době, kdy podobné distinkce ještě nebyly učiněny a například kosmologie byla vykládána meteorologicky. ${ }^{121}$

Ačkoli jsme viděli, že všechny důvody pro nás de facto reprezentují typické rysy iónského myšlení, žádný z nich nemůžeme u Thaléta opravdu explicitně doložit, nebot' se jedná pouze o pozdní vývody. Jakkoli navíc demonstrují jisté Aristotelovo tápání, přesto zároveň představují významné vodítko, abychom porozuměli, jak ze své př́írodovědné pozice iónské myšlení sám vnímal. Aristotelés jasně poukazuje na to, že výběr počátku byl v jeho očích veden představou vzniku života a jeho typických forem. ${ }^{122}$

Sám přitom bezesporu neměl k dispozici žádný př́ípadný Thalétův spis. O jeho existenci ostatně panovala nejistota již v antice. ${ }^{123}$ Vychází tak nejspíše z ústní tradice či z nám blíže neznámého pramene, kterého se dovolává s tím, že se $\mathrm{v}$ něm o Thalétovi $\mathrm{v}$ daném smyslu hovoří. Stejnou dikci zachovává i při dalších příležitostech, kdy Thaléta zmiňuje. V každém případě o Thalétovi panovalo v tradici obecně silné povědomí, přičemž jeho působení bylo zejména spojováno s oblastmi geometrie a astronomie.

Může se zdát proto pozoruhodné, že ve věci důležitosti vody a vlhka je pro nás dnes Aristotelés de facto nejstarším autorem, který ji u Thaléta zmiňuje. Xenofanés, který opakovaně napadá Homéra i Hésioda, měl podle Diogena Laertia podobně vystupovat i proti Thalétovým názorům. ${ }^{124}$ Diogenés ovšem zároveň dodává, že Xenofanés Thaléta ocenil $\mathrm{v}$ souvislosti s jeho úspěchy $\mathrm{v}$ astronomii. Ve stejném smyslu zmiňuje Diogenés i Hérodota, Hérakleita a Démokrita. ${ }^{125}$ Můžeme jen spekulovat o tom, co podnítilo údajnou Xenofanovu kritiku. Zda případná Thalétova svázanost s tradičním myšlením, které je Xenofanovi obvykle trnem v oku, nebo nejasná souvislost právě s vodou jako základním konstituentem života.

Voda se u Thaléta vskutku poněkud vytrácí. Neobjevuje se mnoho dalších kontextů ozřejmujících její životodárné aspekty či případné přímé vazby s Thalétem. Přes občasné výjimky se autoři často omezují na lakonická konstatování, že ji Thalés pokládal za počátek všeho. Jak jsme zmínili, když Aristotelés zasazuje Thalétův výklad do své koncepce příčin, očividně vychází z tradovaných zpráv, které byly nejspíše obecné a kusé. Lze nicméně zmínit ještě další moment, který jej mohl utvrdit v přesvědčení o významné roli vody u Thaléta a podnítit jej k tomu, aby ji označil za Thalétův počátek všeho. Bezprostředně poté, co Aristotelés uvádí vodu jako počátek, se objevuje doplnění, které má uvedený výběr potvrdit: „proto také hlásal, že Země leží na vodě“. Až pak následují Aristotelovy vlastní racionalizující

$124 \quad$ DL IX,18 = DK $21 \mathrm{~A} 1$ 
asociace. Právě kosmologický motiv Země ležící na vodě přitom mohl být konkrétní zprávou, která se $\mathrm{k}$ Thalétovi vztahovala, přičemž zachovávala významnou roli vody.

Když se Aristotelés ve spisu $O$ nebi zabývá pohybem a nehybností Země, přichází s koncepcí, kterou označuje za nejstarší doložené vysvětlení, které zároveň explicitně spojuje s Thalétem:

„Jiní však tvrdí, že [Země] spočívá na vodě. Takový je totiž nejstarší výklad, podle něhož prý Thalés z Mílétu tvrdí, že [Země] setrvává [v klidu], nebot' plave, jako plave dřevo nebo něco podobného. Žádná z takových věcí totiž přirozeně nespočívá na vzduchu, nýbrž na vodě, takže není stejné vysvětlení ohledně Země a vody, která Zemi nese. Ze své přirozenosti totiž nesetrvává nahoře, ale spočívá na něčem. " ${ }^{2126}$

Viděli jsme, že se odkaz na danou koncepci objevuje i v závěru Simplikiova referátu. Stejně jako v př́ípadě pasáže z I. knihy Metafyziky, Aristotelés zde nijak nezastírá svou závislost na přebíraných informacích. A podobně celé pojetí opět spojuje s nejstarší tradicí, do níž zahrnuje Thaléta. Lze si povšimnout, že oproti úryvku v Metafyzice Aristotelés nyní přechází na kritickou nótu, kdy s uvedenou koncepcí polemizuje. Již nepřináší vlastní volné asociace, $v$ nichž by se nesl na „Thalétově vlně“, ale následuje jeho cílená kritika. Mimo jiné se tak jedná o znamení původnosti představovaného výkladu. Navíc jde o naprosto

126 Aristotelés, De caelo II,13,294a28 = DK 11 A 14. konkrétní pojetí, nadto z výsostné oblasti kosmologie. Jak jsme viděli, kosmologie se v archaické době úzce proplétala s meteorologií, a souvisela tak i s popisem života. Uvedená koncepce doslova spojuje oba Aristotelovy texty. Mohla tak sehrát roli pověstného střípku, který zapadl do „mozaiky“ a potvrdil Aristotelovi fundamentální roli vody u prvního z Mílét’anů.

\section{ZÁVĚREM}

Aristotelova reference v I. knize Metafyziky, v níž uvádí Thaléta jako prvního na scénu filosofie, představuje cenné svědectví o Aristotelově přístupu $\mathrm{k}$ archaické filosofii. Ačkoli Thaléta „zakleje“ do koncepce příčin, zároveň předkládá své vlastní důvody, proč Thalés zvolil vodu za počátek. Nezapře přitom svou přírodovědnou orientaci. Jakkoli je veden pouze účelově, jedná se o jistý pokus o porozumění tomuto archaickému mysliteli. Jeho racionalizace domnělých původních důvodů pak vykazuje znaky, které úzce souvisejí zejména se vznikem, s projevy a s uchováním života. Zároveň představují příznačné oblasti spojené s archaickou filosofií. Je proto možné, že celá pasáž přece jen směřuje $\mathrm{k}$ jádru Thalétovy výpovědi. Uplatněním koncepce př́ičin však Aristotelés musel nutně dospět k odlišným závěrům. Přesto nabízí způsob, jak celému pojetí rozumět i mimo peripatetické schematismy.

Je evidentní, že Aristotelés jednal pouze na základě zprostředkovaných a kusých informací, které měl k dispozici. Lze se domnívat, že Thalétovi přiřkl vodu za počátek zejména na základě Mílétanova spojení se starou tradicí, 
v níž voda sehrávala významnou úlohu. Thalés soudil, že Země spočívá na vodě. Nelze ovšem pochybovat o tom, že atri- Tato zpráva mohla být ve skutečnosti dobuty náležející vodě byly i zde primárně konce určující, nebot pochází z klíčové odvozeny z jejích vlastností úzce spja- kosmologické oblasti, která měla být tých se životem. Aristotelés se ale záro- spolu s geometrií jednou z Thalétových veň mohl opřít o informaci, podle níž domén. 


\section{ZKRATKY}

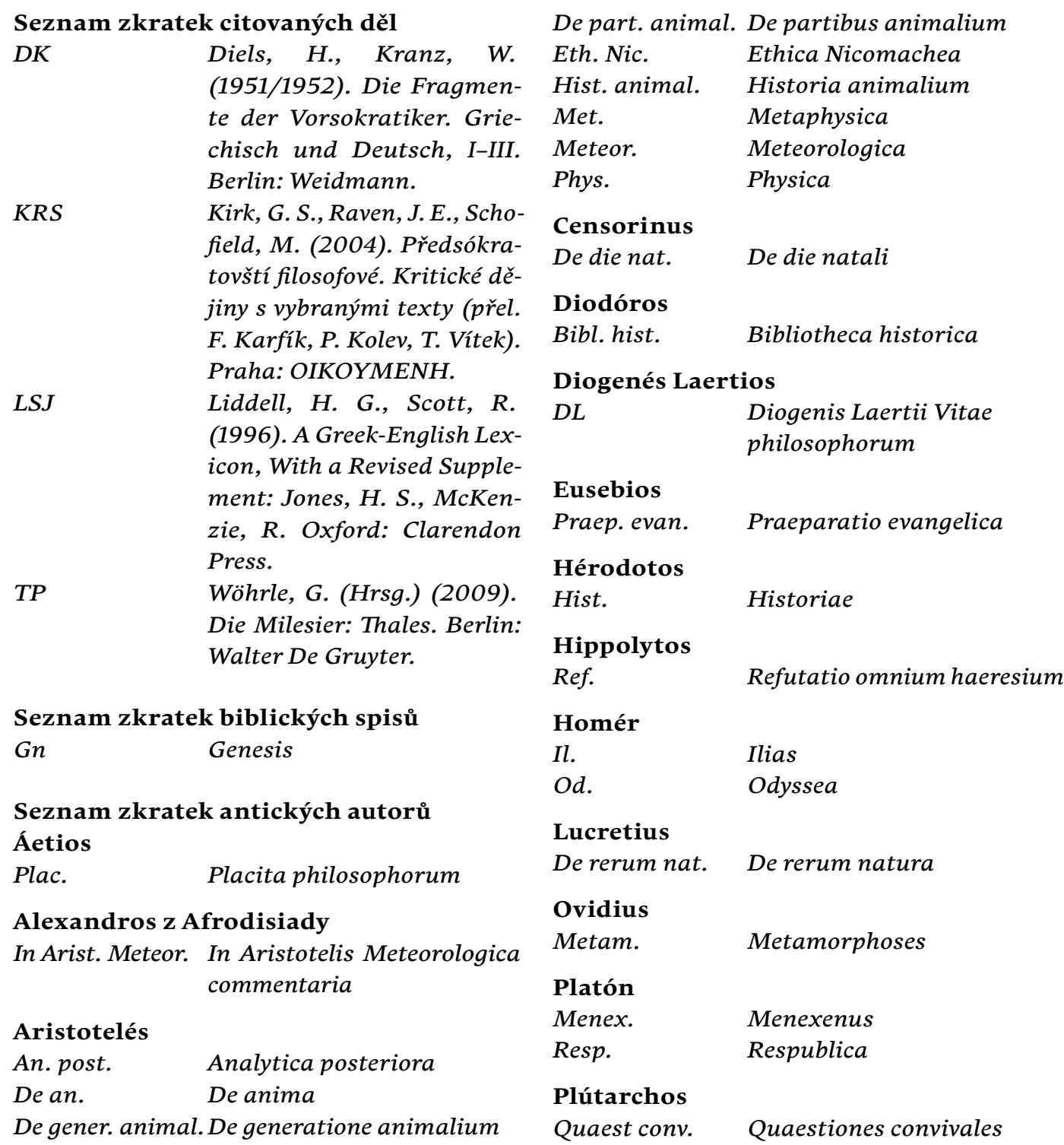


Porfyrios

Ad Gaur.

Ad Gaurum quomodo animetur fetus

Pseudo-Plútarchos

Strom. Stromata

Sextos Empeirikos

Adv. math. Adversus mathematicos

\section{Simplikios}

In Arist. De caelo In Aristotelis De caelo commentaria

In Arist. Phys. In Aristotelis Physicorum libros commentaria

Theofrastos

Hist. plant.

Historia plantarum

\section{BIBLIOGRAFIE}

\section{Prameny}

Diels, H. (1879). Doxographi Graeci. Berlin: G. Reimer.

Diels, H., Kranz, W. (1951/1952). Die Fragmente der Vorsokratiker. Griechisch und Deutsch, I-III. Berlin: Weidmann.

Graham, D. W. (2010). The Texts of Early Greek Philosophy. The Complete Fragments and Selected Testimonies of the Major Presocratics, I. Cambridge: Cambridge University Press.

Mansfeld, J., Runia, D. T. (2009). Aëtiana. The Method and Intellectual Context of a Doxographer, II, The Compendium 1. Leiden, Boston: Brill.

Marcovich, M. (1986). Hippolytus, Refutatio omnium haeresium. Berlin: Walter de Gruyter.
Marcovich, M. (2008). Diogenis Laertii Vitae philosophorum, I. Berlin: Walter de Gruyter.

Wöhrle, G. (ed.) (2009). Die Milesier: Thales. Berlin: Walter De Gruyter.

Wöhrle, G. (ed.) (2012). Die Milesier: Anaximander und Anaximenes. Berlin: Walter de Gruyter.

\section{České překlady pramenů}

Není-li uvedeno jinak, překlady antických autorů pořídil na základě starších překladů V. Hladký a kol.

Uváděné překlady antických autorů od Z. Kratochvíla byly převzaty z Fysis.cz. Dostupné [online] z: <http://www.fysis.cz> [cit. 31. 7. 2016].

Homér (1942). Ílias (přel. O. Vaňorný). Praha: J. Laichter. 


\section{Slovníky}

Liddell, H. G., Scott, R. (1996). A Greek-English Lexicon, With a Revised Supplement: Jones, H. S., McKenzie, R. Oxford: Clarendon Press.

\section{Sekundární literatura}

Barnes, J. (1982). The Presocratic Philosophers. London: Routledge \& Kegan Paul.

Campbell, G. L. (2000). „Zoogony and Evolution in Plato's Timaeus: the Presocratics, Lucretius and Darwin“. In: M. R. Wright (ed.), Reason and Necessity. Essays on Plato's Timaeus. London: Duckworth, s. $145-180$.

Campbell, G. L. (2006). Strange Creatures. Anthropology in Antiquity. London: Duckworth.

Finkelberg, A. (1993). „Anaximander's Conception of the Apeiron“. Phronesis 38, s. 229-256.

Graham, D. W. (2006). Explaining the Cosmos. The Ionian Tradition of Scientific Philosophy. Princeton: Princeton University Press.

Graham, D. W. (2010). The Texts of Early Greek Philosophy. The Complete Fragments and Selected Testimonies of the Major Presocratics, I. Cambridge: Cambridge University Press.

Graham, D. W. (2013). Science Before Socrates. Parmenides, Anaxagoras, and the New As- tronomy. Oxford, New York: Oxford University Press.

Guthrie, W. K. C. (1962). A History of Greek Philosophy. I. The Earlier Presocratics and the Pythagoreans. Cambridge: Cambridge University Press.

Guthrie, W. K. C. (1965). A History of Greek Philosophy. II. The Presocratic Tradition from Parmenides to Democritus. Cambridge: Cambridge University Press.

Guthrie, W. K. C. (1986). In the Beginning. Some Greek views on the Origins of Life and the Early State of Man. Westport, Conn.: Greenwood Press.

Hladký, V., Kočandrle, R., Kratochvíl, Z. (2012). Evoluce před Darwinem. Nejstarší vývojová stadia evoluční nauky. Červený Kostelec: Pavel Mervart.

Hobza, P. (2015). , Je skutečně zjevné, že Aristotelovi předchůdci hovořili o příčinách? (Met. 983b3)“. Aither 13, s. 46-55.

Cherniss, H. F. (1935). Aristotle's Criticism of Presocratic Philosophy. Baltimore: the Johns Hopkins press.

Kahn, Ch. H. (1960). Anaximander and the Origins of Greek Cosmology. New York: Columbia University Press.

Kirk, G. S., Raven, J. E., Schofield, M. (2004). Předsókratovští filosofové. Kritické dějiny s vybranými texty (přel. F. Karfík, P. Kolev, T. Vítek). Praha: OIKOYMENH. 
Kočandrle, R. (2013). „Anaximenova duše“. Aither 9, s. 6-44.

Kočandrle, R. (2014). Anaximenés z Mílétu. Červený Kostelec: Pavel Mervart.

Kočandrle, R., Kleisner, K. (2011). „Evoluce ve vlhku zrozená: analogie a paralely Anaximandrovy pra-evoluce a darwinovské evoluce“. Dějiny věd a techniky 4, s. 219-263.

Kočandrle, R., Kleisner, K. (2013). „Evolution Born of Moisture: Analogies and Parallels Between Anaximander's Ideas on Origin of Life and Man and Later Pre-Darwinian and Darwinian Evolutionary Concepts“. Journal of the History of Biology 46, s. 103-124.

Kratochvíl, Z. (2010). Mezi mořem a nebem. Odkaz iónské archaické vnímavosti. Červený Kostelec: Pavel Mervart.
Lloyd, G. E. R. (1964). „The Hot and the Cold, the Dry and the Wet in Greek Philosophy“. The Journal of Hellenic Studies 84, s. 92-106.

Loenen, J. H. (1954). „Was Anaximander an Evolutionist?“. Mnemosyne 7, s. 215-232.

McDiarmid, J. B. (1953). „Theophrastus on the Presocratic Causes". Harvard Studies in Classical Philology 61, s. 85-156.

O'Grady, P. F. (2002). Thales of Miletus. The Beginnings of Western Science and Philosophy. Burlington, VT: Ashgate.

Polák, M. (2013). Filosofie mysli. Praha: Triton.

Stupňánek, B. (2010). „Vztah Anaximandrovy zoogonie a antropogonie“. Pro-Fil 1, s. $37-54$. 